FEDERAL RESERVE BANK of ST. LOUIS

\section{RESEARCH DIVISION} Working Paper Series

\title{
Monetary Policy, the Tax Code, and the Real Effects of Energy Shocks
}

\author{
William T. Gavin, \\ Benjamin D. Keen \\ and \\ Finn E. Kydland
}

Working Paper 2013-019B

https://doi.org/10.20955/wp.2013.019

March 2014

FEDERAL RESERVE BANK OF ST. LOUIS

Research Division

P.O. Box 442

St. Louis, MO 63166

The views expressed are those of the individual authors and do not necessarily reflect official positions of the Federal Reserve Bank of St. Louis, the Federal Reserve System, or the Board of Governors.

Federal Reserve Bank of St. Louis Working Papers are preliminary materials circulated to stimulate discussion and critical comment. References in publications to Federal Reserve Bank of St. Louis Working Papers (other than an acknowledgment that the writer has had access to unpublished material) should be cleared with the author or authors. 


\title{
Monetary Policy, the Tax Code, and the Real Effects of Energy Shocks*
}

\author{
William T. Gavin
}

\author{
Benjamin D. Keen
}

March 14, 2014

\author{
Finn E. Kydland
}

\begin{abstract}
This paper develops a monetary model with taxes to account for the time-varying effects of energy shocks on output and hours worked in post-World War II U.S. data. In our model, the real effects of an energy shock are amplified when the monetary authority responds to that shock by changing its inflation objective. Specifically, higher inflation raises households' nominal capital gains taxes since those taxes are not indexed to inflation. The increase in taxes behaves as a negative wealth effect and generates an immediate decline in output, investment, and hours worked. The large drop in investment then causes a gradual but very persistent decline in the capital stock. That protracted decline in the capital stock is associated with an extended period of low labor productivity and high inflation. The real effects from the increase in nominal capital gains taxes are magnified by the tax on nominal interest income, which is also not indexed to inflation. A prolonged period of higher inflation and lower labor productivity following a negative energy shock is consistent with the stagflation of the 1970s. The negative effects, however, subsided greatly after 1980 due to the Volcker disinflation policy which prevented the Fed from accommodating negative energy shocks with higher inflation.

Key words: Inflation, Realized Capital Gains, Tax Code, Energy Shocks

JEL Classification: E32; E52; E62
\end{abstract}

*Gavin, Research Division, Federal Reserve Bank of St. Louis, St. Louis, MO (gavin@stls.frb.org); Keen, Department of Economics, University of Oklahoma, Norman, OK (ben.keen@ou.edu); Kydland, Department of Economics, University of California, Santa Barbara, CA (kydland@econ.ucsb.edu). Benjamin D. Keen and Finn E. Kydland thank the Federal Reserve Banks of Dallas and St. Louis for research support on this project. The research benefited from helpful comments of participants at the AMES 2011 in Seoul, the Tsinghua Macroeconomic Workshop 2011 in Beijing, the SED 2011 meetings in Ghent, and the CEF 2012 meetings in Prague. We also thank Fei Mao for research assistance on an earlier version of the paper. 


\section{Introduction}

Research economists over the past 35 years have worked to understand the effects of energy shocks on aggregate fluctuations. One problem is to justify theoretically how an energy shock could have such a large impact on output and hours worked when energy is such a small factor in production. Another problem is to explain why the negative impact of higher energy prices moderated so much after 1983.

In this paper, we develop a monetary model with taxes to account for the time-varying effects of energy shocks on output and hours worked. The model includes energy as a consumption good and as a third factor in a CES production function with capital and labor. It also incorporates taxes on income from labor, capital, bonds, and realized capital gains. All of the real income from capital is taxed as capital income paid out on an accrual basis. In our model, all capital gains are due to increases in the nominal price of capital. Shifts in the monetary policy regime change the way in which inflation expectations respond to energy shocks. Monetary policy has real effects because shifts in inflation expectations change the expected tax on bond interest income and capital gains.

This paper replicates the dynamics observed between energy shocks and real economic activity from the 1970s in a real business cycle (RBC) model with energy shocks, accommodative monetary policy, and the taxation of nominal capital gains and bond interest income. Our model captures the nuance that capital gains are taxed only when they are realized. In our framework, energy shocks directly affect output and hours worked by altering the relative price of energy. Those direct effects are amplified by indirect effects that operate through the interaction between monetary policy and the tax code and can be larger in size than the direct effects.

The model is used to compute the effects of energy shocks under alternative policy regimes, which are calibrated to post-World War II U.S. data. We find that energy shocks had a large impact on the real economy before 1980 because the Fed allowed the implicit inflation target to change in response to those shocks. Medium- to long-run inflation expectations rose with adverse shocks to the energy supply. Higher expected inflation increased the expected taxes on capital gains, which caused an immediate decline in output and hours worked. That effect was amplified by the tax on bond interest income. Beginning in October 1979, Fed Chairman Paul Volcker announced a shift toward an aggressive anti-inflation policy. After that successful regime shift, the Fed no longer adjusted its inflation rate target in response to energy shocks, which may explain the substantially diminished effect of energy shocks on the real economy, as documented in Hooker (1996).

The next section briefly reviews the literature on the macroeconomic consequences of energy shocks. Following that, we describe the model used in this study with an emphasis on the tax code and the role of energy. We calibrate the model based on long-run relationships and microeconomic studies. Our results show that a monetary policy that accommodates energy price hikes can have large effects on the real economy, both in the short run on output and hours worked and in the long run on capital and productivity.

\section{Energy Shocks in the U.S. Postwar Economy}

In this paper, energy shocks represent supply shocks to all forms of energy with the understanding that, historically, the largest shocks to the U.S. energy supply have been to the supply of crude oil. Because of the quality and availability of data, our model is calibrated to data on energy consumed 
by U.S. households despite the fact that the model has energy in consumption and production. We model the energy shock as an exogenous innovation to supply. Overall, our paper contributes to a large literature on the empirical regularities of oil prices, output, and inflation by examining the interaction between taxation and monetary policy.

Hamilton $(1983,2009)$ documents that all but one of the post-World War II recessions were preceded by a significant increase in the price of crude oil. The tripling of oil prices prior to the deep recession of 1974 had a profound impact on the conventional wisdom about the effects of energy shocks. Following a sharp rise in oil prices, initial estimates from January 1976 indicate that GDP declined 7.7 percent from the business cycle peak in 1973:Q4 to the trough in 1975:Q1. In comparison, initial estimates in January 2010 of the "Great Recession" indicate that GDP fell only 3.7 percent from its 2007:Q4 peak to the 2009:Q2 trough. ${ }^{1}$ That large GDP decline in 1974 motivated economists to examine the effects of energy shocks on the real economy.

Baily (1981) argues that the capital stock in place prior to 1973 was dependent on low-price energy and that the sharp rise in the relative price of oil caused a substantial share of the capital stock to become obsolete. Wei (2003) develops a general equilibrium model with putty-clay investment and shows that this feature cannot account for either the magnitude of the declines in output and hours worked or the large drop in equity prices that occurred in 1973-1974. Alpanda and PeraltaAlva (2010) show that Wei's results for equity prices depend on the particular method she utilizes to define investment. Using a standard definition of investment and the putty-clay model of capital, Alpanda and Peralta-Alva (2010) find that the oil shock could explain about half of the decline in equity prices; but, like Wei (2003), they cannot explain the large drop in output and hours worked.

The failure of the U.S. economy to respond positively to the oil price declines of 1986 and the mild recession following the oil price hikes of 1990 led researchers to ask whether changes in the oil market could explain the moderation in aggregate volatility that occurred around 1983 (the "Great Moderation"). Part of the decrease in volatility is attributable to a decline in the size of shocks and part is due to an increase in the efficiency of energy use, as the ratio of energy consumption to GDP fell by about half from 1974 to 2008. Although most studies assume a break in the early 1980s, with distinct periods of high and low efficiency, the actual change in the ratio of energy use to GDP occurs around 1973-1974. Energy use prior to 1973 grew at about the same rate as real GDP. After 1973, per capita energy use remained relatively constant, while per capita real GDP continued to grow.

Rotemberg and Woodford (1996) argue that monopolistic competition is needed to capture the large effects of oil prices on the economy. Finn (2000) shows that making capacity utilization and the depreciation rate dependent on energy use has the same relative effect as introducing monopolistic competition. Leduc and Sill (2004) determine that the monetary policy rule matters in a general equilibrium model with oil prices. Specifically, they find that the Fed negatively affected output following the 1970s oil price shocks because they overtightened the money supply after each shock. Aguiar-Conraria and Wen (2007) develop a model with increasing returns to scale and a multiplier-accelerator mechanism that tracks the real economy very well following the 1973 oil price shock, but cannot explain why the economy does not respond to later oil price shocks in a similar way.

Dhawan, Jeske, and Silos (2010) offer an empirical explanation for the large effects of energy

\footnotetext{
${ }^{1}$ The vintage data sets can be found at the Federal Reserve Bank of Philadelphia's website: http://www.philadelphiafed.org/research-and-data/real-time-center/real-time-data/data-files/ROUTPUT/.
} 
shocks during the 1970s. Using a Markov-switching model with shocks to energy prices and total factor productivity, they find that energy shocks have a spillover effect on total factor productivity that has a large and significant impact on output prior to 1983. The model then switches in 1983, and the post-1983 estimates show that the spillover effect disappears. They do not, however, offer an economic explanation for the spillover that amplifies the effect of energy shocks on output or a reason why it disappears. Our model provides a theory that could account for their results.

Although all of those papers make important contributions to the literature, none of them examines the effects of energy shocks in a model with taxes. This paper investigates the impact that taxes and monetary policy have on the response of key economic variables to an energy shock. Our results provide a potential theoretical explanation for the large real effects generated following an energy shock prior to the early 1980s and the small real effects observed afterward.

\section{The Model}

This paper develops a RBC model with taxation to examine the impact of an energy shock when the central bank endogenously adjusts its inflation target to that shock. Our model incorporates an energy sector into Gavin, Kydland, and Pakko's (2007) monetary policy model with taxation. Energy in our specification is both a consumption good and a factor of production. The government taxes four sources of household income: labor, bond interest, capital, and realized capital gains. Labor and capital income taxes affect the steady state, but do not have a measurable effect on business cycle dynamics. Capital gains are modeled such that households can choose when their capital gains are realized (and taxable) subject to some adjustment costs.

\subsection{Energy}

Each period, the economy is endowed with a level of energy, $e_{t}$, which follows an AR(1) process:

$$
\ln \left(e_{t} / e\right)=\rho_{e} \ln \left(e_{t-1} / e\right)+\sigma_{e} \varepsilon_{e, t},
$$

where $e$ is the steady-state level of $e_{t}, 0 \leq \rho_{e}<1, \sigma_{e}>0$, and $\varepsilon_{e, t} \sim N(0,1)$. Energy is purchased in a perfectly competitive market for a price of $P_{e, t}$ by households for consumption, $e_{c, t}$, and by firms for use in the production process, $e_{y, t}$, such that

$$
e_{t}=e_{c, t}+e_{y, t}
$$

Finally, the profits from the energy sector, $T_{t}^{e}=P_{e, t} e_{t}$, are remitted to the households via a lumpsum payment. $^{2}$

\footnotetext{
${ }^{2}$ We also solved the model assuming that the price of energy was exogenous. Our qualitative results are basically the same with either a price or quantity shock. A major problem with defining energy shocks by innovations to its price series is that energy prices are much more volatile than energy quantities in the late period. If energy prices are assumed to be exogenous, we get unrealistically large direct effects of energy on output in the late period, even with reduced energy shares in consumption and aggregate output. Our intuition, as noted in Kilian (2009), is that fluctuations in world energy demand have made energy prices more volatile and less predictable. Newly-formed commodity derivative markets and sophisticated distribution systems, however, have enabled firms to hedge much of the risk caused by the increase in price volatility, which has insulated output from those price variations.
} 


\subsection{Firms}

Since energy, $e_{y, t}$, is an input into the production of non-energy output, $y_{n, t}$, we use a CES production function for non-energy output. ${ }^{3}$ Specifically, non-energy output is produced by combining labor, $n_{t}$, capital, $k_{t}$, and energy inputs with a stochastic level of technology, $z_{t}$, and a nonstochastic level of labor-augmenting technological progress, $x_{t}$, such that

$$
y_{n, t}=z_{t}\left(\psi k_{t}^{v_{f}}+(1-\psi) e_{y, t}^{v_{f}}\right)^{\alpha / v_{f}}\left(x_{t} n_{t}\right)^{1-\alpha},
$$

where $\psi>0$ represents the steady-state ratio of energy used in production to capital, $v_{f}$ is the elasticity of substitution between energy and capital, and $0<\alpha<1$. The stochastic technology factor, $z_{t}$, follows an $\mathrm{AR}(1)$ process:

$$
\ln \left(z_{t} / z\right)=\rho_{z} \ln \left(z_{t-1} / z\right)+\sigma_{z} \varepsilon_{z, t},
$$

where $z$ is the steady-state level of $z_{t}, 0 \leq \rho_{z}<1, \sigma_{z}>0$, and $\varepsilon_{z, t} \sim N(0,1)$. Lastly, the laboraugmenting technological progress, $x_{t}$, increases at a deterministic gross growth rate of $\gamma^{1 /(1-\alpha)}$.

Each period, firms sell non-energy output in a perfectly competitive market at a price of $P_{n, t}$ and purchase labor, capital services, and energy in competitive markets for a nominal wage of $W_{t}$, a nominal capital rental rate of $P_{n, t} q_{t}$, and an energy price of $P_{e, t}$, respectively, where $q_{t}$ is the real rental rate of capital. Firms' profit maximization under the assumption of perfect competition implies that the nominal wage, the nominal capital rental rate, and the price of energy equal the price of non-energy output multiplied by the marginal products of labor, capital, and energy, respectively. Aggregate output, $y_{t}$, then is calculated as follows:

$$
P_{t} y_{t}=P_{n, t} y_{n, t}+P_{e, t} e_{t}
$$

where $P_{t}$ is the aggregate price level, which is

$$
P_{t}=P_{n, t}^{\left(1-\omega_{y}\right)} P_{e, t}^{\omega_{y}}
$$

and $\omega_{y}=P_{e} e /\left(P_{n} y_{n}+P_{e} e\right)$ is energy's share of aggregate output in the steady state.

\subsection{Households}

Households gain a discounted stream of expected utility from consumption, $c_{t}$, and leisure, $l_{t}$,

$$
E_{0}\left[\sum_{t=0}^{\infty} \beta^{t} \frac{\left(c_{t}^{\theta} l_{t}^{1-\theta}\right)^{1-\zeta}}{1-\zeta}\right],
$$

where $E_{0}$ is the expectational operator at time 0 , the discount factor is $0<\beta<1$, the intertemporal elasticity of consumption is $1 / \zeta>0$, and the preference parameter $\theta$ is between 0 and 1 . The

\footnotetext{
${ }^{3}$ A similar production function has been used in other macroeconomic studies of energy effects. See, for example, Kim and Loungani (1992), Alpanda and Peralta-Alva (2010), and Dhawan, Jeske, and Silos (2010). See Díaz and Puch (2013) for an explanation of the time-varying role of energy in output production based on a complex production function that studies the interaction of the traditional separate investment specific technology factor with an independent technology factor that affects the energy efficiency built into capital goods.
} 
households' consumption good is a CES composite of non-energy consumption, $c_{n, t}$, and energy consumption,

$$
c_{t}=\left(b_{1} c_{n, t}^{v_{h}}+b_{2} e_{c, t}^{v_{h}}\right)^{1 / v_{h}}
$$

where $v_{h}$ is the elasticity of substitution between non-energy and energy consumption and $b_{1}$ and $b_{2}$ are constants that are calibrated such that $b_{1}\left(c_{n, t} / c_{t}\right)^{v_{h}}$ and $b_{2}\left(e_{n, t} / c_{t}\right)^{v_{h}}$ are set equal to nonenergy's and energy's shares of consumption, respectively.

The endowment of time available to households is normalized to one in order to identify the fraction of time households spend on leisure, $l_{t}$, work, $n_{t}$, and adjusting their financial portfolio, $s_{t}$ :

$$
l_{t}+n_{t}+s_{t}=1 \text {. }
$$

The time households spend adjusting their portfolio, $s_{t}$, is the shopping-time cost associated with holding money balances. Specifically, the shopping-time cost increases as the ratio of nominal consumption spending to the amount of money carried over from the previous period, $M_{t-1}$, rises:

$$
s_{t}=\chi\left(\frac{P_{t} c_{t}}{M_{t-1}}\right)^{\eta},
$$

where $\chi>0$ is a scale parameter and $\eta>0$ is the curvature parameter in the money-time trade-off.

Households, who own the capital, rent it to the firms and select their level of investment, $i_{t}$, such that

$$
k_{t+1}=i_{t}+(1-\delta) k_{t}
$$

where $\delta$ is the depreciation rate. As the nominal value of their capital stock changes, households accrue capital gains (or losses), but can choose when those capital gains are realized. The timing is important because realized capital gains, $G_{t}$, are taxed by the government at a distortionary rate of $\tau^{G}$. Specifically, households manage their level of unrealized capital gains, $U_{t}$, subject to some capital gains adjustment costs, $A C_{t}$,

$$
U_{t+1}=U_{t}+\left(P_{n, t}-P_{n, t-1}\right) k_{t}-G_{t}+A C_{t},
$$

where $\left(P_{n, t}-P_{n, t-1}\right) k_{t}$ are the capital gains accrued in period $t$. Those adjustment costs,

$$
A C_{t}=G_{t}-\Phi\left(G_{t} / U_{t}\right) U_{t}
$$

represent the penalty households incur to delay the realization of capital gains. ${ }^{4}$ The capital gains adjustment costs are assumed to be zero in the steady state (i.e., $\Phi(G / U)=G / U$ ). We also assume that it is less costly to realize capital gains sooner rather than later, so that $\Phi^{\prime}(\cdot)>0$ and $\Phi^{\prime \prime}(\cdot)<0$. In an accrual system, the expression $\Phi^{\prime}\left(G_{t} / U_{t}\right)$ is equal to unity. ${ }^{5}$

\footnotetext{
${ }^{4}$ When the realization of capital gains is deferred, the capital gains adjustment costs penalize households with extra unrealized capital gains which are in addition to the amount of capital gains deferred. Those higher levels of unrealized capital gains do not change the size of the capital stock but, instead, simply increase the future tax liability of households.

${ }^{5}$ See Anagnostopoulos, Cárceles-Proveda, and Lin (2012) for an analysis of capital gains taxation when taxes are paid on an accrual basis.
} 
Households begin each period with their initial nominal money balances, $M_{t-1}$, and receive the principal plus after-tax interest from their nominal bond holdings, $\left(1+\left(1-\tau^{B}\right)\left(R_{t-1}-1\right)\right) B_{t-1}$, where $R_{t}$ is the gross nominal interest rate on bond holdings, $B_{t}$, from period $t$ to $t+1$. During the period, households receive after-tax earnings from labor, $\left(1-\tau^{n}\right) W_{t} n_{t}$, after-tax earnings from their capital income, $\left(\left(1-\tau^{k}\right) q_{t}+\tau^{k} \delta\right) P_{n, t} k_{t}$, government transfer payments, $T_{t}^{G}$, and profits from the energy sector, $T_{t}^{E}$, where $\tau^{B}, \tau^{n}$, and $\tau^{k}$ are the distortionary tax rates that apply to bond interest income, labor income, and capital income, respectively. Those funds are utilized by households to finance their purchases of non-energy consumption goods, $P_{n, t} c_{n, t}$, investment goods, $P_{n, t} i_{t}$, energy consumption, $P_{e, t} e_{c, t}$, and to pay taxes on realized capital gains. The remaining funds are used by households to purchase bonds, $B_{t}$, and acquire end-of-period money balances, $M_{t}$. Thus, the households' nominal budget constraint is

$$
\begin{aligned}
P_{n, t}\left(c_{n, t}+i_{t}\right)+P_{e, t} e_{c, t}+B_{t}+M_{t}+\tau^{G} G_{t}= & \left(1+\left(1-\tau^{B}\right)\left(R_{t-1}-1\right)\right) B_{t-1}+M_{t-1} \\
& +\left(\left(1-\tau^{k}\right) q_{t}+\tau^{k} \delta\right) P_{n, t} k_{t} \\
& +\left(1-\tau^{n}\right) W_{t} n_{t}+T_{t}^{G}+T_{t}^{E}
\end{aligned}
$$

\subsection{Government}

The government collects revenue by printing money, $T_{t}^{M}=M_{t}-M_{t-1}$, and taxing labor income, bond interest income, capital income, and nominal capital gains. It then redistributes all tax revenue back to households in the form of a lump-sum payment, $T_{t}^{G}$. Therefore, the government's budget constraint is

$$
T_{t}^{G}=\tau^{n} W_{t} n_{t}+\tau^{k}\left(q_{t}-\delta\right) P_{n, t} k_{t}+\tau^{B}\left(R_{t-1}-1\right) B_{t}+\tau^{G} G_{t}+T_{t}^{M} .
$$

The government, via its central bank, sets monetary policy using a nominal interest rate rule:

$$
\ln \left(\frac{R_{t}}{R}\right)=\left(1+\phi_{\pi}\right) \ln \left(\frac{\pi_{t}}{\pi_{t}^{*}}\right)+\phi_{y} \ln \left(\frac{y_{n, t}}{y_{n}}\right),
$$

where $\pi_{t}=P_{t} / P_{t-1}$ is the aggregate inflation rate, $\pi_{t}^{*}$ is the time-varying inflation rate target, $y_{n}$ is steady-state non-energy output, $\phi_{\pi}>0$, and $\phi_{y}>0$. Prior to January 2012, the Fed did not have an explicit inflation rate target but, instead shifted their implied target over time. We incorporate that concept into our model by assuming that the central bank's inflation target adjusts in response to energy supply shocks:

$$
\ln \left(\pi_{t}^{*} / \pi^{*}\right)=\rho_{\pi} \ln \left(\pi_{t-1}^{*} / \pi^{*}\right)-\xi \sigma_{e} \varepsilon_{t}^{e},
$$

where $\xi \geq 0$ is the central bank's endogenous response of monetary policy to energy shocks, $\pi^{*}$ is the steady-state inflation rate target, and $0 \leq \rho_{\pi}<1$. Finally, the money stock under any nominal interest rate rule is determined endogenously from the households' money demand.

\section{Equilibrium and Calibration}

The equations representing our model's first-order conditions, identity equations, and exogenous shocks comprise the set of difference equations that generate the model's systematic equilibrium. 
To obtain a stationary equilibrium, the nominal and real trends in the model data are eliminated by dividing the nominal variables by $\gamma^{t} P_{t}$ and the real variables with a deterministic trend by $\gamma^{t}{ }^{6}$ Given that all of the transformed variables are stationary, the model's nonstochastic steady-state equilibrium can be determined. We then linearize the system of equations around its nonstochastic steady state and apply standard techniques to find the linearized model's solution.

\subsection{Calibration}

We consider and label two monetary policy regimes (early and late), which are calibrated to periods with different energy shares and distinctly different monetary policies. The early regime is calibrated to a period, 1973:Q1-1979:Q3, roughly spanning the time between the end of the Bretton Woods fixed exchange rate system and the beginning of the Volcker monetary policy reform in October 1979. We ignore the short period, October 1979 through October 1982, during which the Fed targeted a reserve quantity rather than the federal funds rate. The late regime is calibrated to a later period, 1983:Q1-2007:Q4. ${ }^{7}$ Therefore, we exclude the beginning of the financial crisis and a period in which monetary policy was constrained by the zero lower bound on nominal interest rates. Parameter assignments for the two monetary policy regimes are discussed below and summarized in Table 1. With the exception of the energy shares and the monetary policy parameters, all of the structural parameters are the same across both regimes.

We calibrate the quarterly discount factor, $\beta$, to be equal to 0.99 . The quarterly gross steadystate inflation rate is 1.01 , which assumes a trend annual inflation rate of 4 percent in both the early and late periods. The gross quarterly real growth rate, $\gamma$, is set to 1.004 in order to match the U.S. post-World War II average annual per capita real GDP growth rate of 1.6 percent.

Capital's share of output, $\alpha$, is fixed to 0.33 . The persistence of the technology shock, $\rho_{z}$, is assumed to be equal to 0.95 in both periods, while the standard deviation of the technology shock is set to 0.59 percent per quarter in the early period and 0.47 percent in the late period. Those values are estimated using residuals from the output equation in a bivariate VAR including energy and output, which are discussed in detail below. The elasticity of substitution between energy and capital, $v_{f}$, is set to -0.9 , which is larger in absolute value than the -0.7 used by Kim and Loungani (1992) and Dhawan, Jeske, and Silos (2010). When $v_{f}=-0.7$, the price elasticity of demand for energy is about unity. Empirical estimates, however, suggest that the price elasticity of energy is greater than 2 . Therefore, we assume $v_{f}=-0.9$ because that calibration generates the most price-inelastic short-run factor demand for our model (around 1.5). A parameterization of $v_{f}<0$ also signifies that energy and capital are complements in the production process. Parameter $\psi$ is set so that energy's share in the production of output is 5.3 percent in the early period and 3.7 percent in the late period based on work by Alpanda and Peralta Alva (2010). The steady-state relative prices of energy and non-energy are assumed to be equal $\left(P_{n}=P_{e}\right)$. Persistence in the energy series, $\rho_{e}$, is equal to 0.92, which is obtained from the estimates in Dhawan, Jeske, and Silos (2010). The standard deviation of the energy shock, $\sigma_{e}$, is calibrated using estimates from

\footnotetext{
${ }^{6}$ Since the variables in the time constraint, $n_{t}, l_{t}$, and $s_{t}$, do not have a deterministic trend, they are not divided by $\gamma^{t}$.

${ }^{7}$ Our two monetary policy regimes are roughly consistent with Schorfheide's (2005) estimates of a high-inflation regime from the early 1970s to the Volcker stabilization policy at the beginning of the 1980s and a low-inflation regime following that time period.
} 
our bivariate VAR with energy and output. That is, $\sigma_{e}$ is set to 2.81 percent in the early period and 1.26 percent in the late period as discussed below.

Turning to the households sector, the preference parameter, $\theta$, is specified to be consistent with Ghez and Becker's (1975) panel-data estimates in which households spend approximately 30 percent of their available time working. The risk-aversion parameter, $\sigma$, is set equal to 2 , while the quarterly depreciation rate, $\delta$, is assumed to be 2.5 percent. Our parameterization of $b_{1}$ and $b_{2}$ from the CES component of the utility function is consistent with the average ratio of energy used in consumption to aggregate consumption, 0.072 in the early period (1969:Q1-1979:Q3) and 0.046 in the late period (1983:Q1-2007:Q4). The elasticity of substitution between energy and non-energy consumption, $v_{h}$, is set to -0.9 in order to generate a high degree of short-run inelasticity in energy demand. The shopping-time parameter $\eta$ is set to -1 . That calibration implies that the interest rate elasticity of money demand is -0.5 , which is consistent with empirical evidence summarized by Mulligan and Sala-i-Martin (1997) and Lucas (2000). The scale parameter $\chi$ is specified such that, in the steady state, households spend an additional 1 percent of their working time adjusting their portfolio, $s$, or 0.3 percent of their total available time.

The tax rates are calibrated based on the average marginal tax rates for 1960 to 2002 from the NBER TAXSIM model. ${ }^{8}$ Specifically, the tax rate is set to 24.4 percent for labor income, 25.8 percent for bond interest income, 34.1 percent for capital income, and 20.2 percent for realized capital gains. We assume that capital gains adjustment costs are present when the economy deviates from its steady state but are zero at the steady state (i.e., $\Phi(G / U)=G / U$ ). Since the model is solved using linearizing approximation methods, we need to identify the parameter values only for $\Phi, \Phi^{\prime}(\cdot)$, and $\Phi^{\prime \prime}(\cdot)$ and do not have to specify a functional form for $\Phi\left(G_{t} / U_{t}\right)$. The value for $\Phi^{\prime}(\cdot)$ is calibrated, so that the steady-state ratio of realized capital gains to accrued capital gains, $G /((1-1 / \pi) k)$, is $0.4 .^{9}$ As for $\Phi^{\prime \prime}(\cdot)$, that value is determined by setting the elasticity of the marginal capital gains adjustment costs with respect to $G / U,(G / U) \Phi^{\prime \prime}(\cdot) / \Phi^{\prime}(\cdot)$, equal to $-1.1 .^{10}$

In both periods, we assume that the Fed follows a standard Taylor (1993) rule, where $\phi_{\pi}$ and $\phi_{y}$ are set equal to 0.5 and 0.125 , respectively. When a nominal bond income tax is present in a model with a Taylor-type monetary policy rule, the inflation coefficient in the policy rule, $1+\phi_{\pi}$, must be noticeably larger than one to ensure the model has a unique equilibrium. The determinacy condition in our model is simplest to calculate when $\phi_{y}=0 .{ }^{11}$ This condition is given as:

$$
\left(1-\frac{\beta \tau^{B}}{\pi \gamma}\right)\left(1+\phi_{\pi}\right)>1 .
$$

The condition necessary for model determinacy when $\tau^{B}=0$ and $\phi_{y}=0$ is just the Taylor princi-

\footnotetext{
${ }^{8}$ See Table 9 in Feenberg and Poterba (2003).

${ }^{9}$ Over the sample period, realized capital gains are equal to about 40 percent of accrued capital gains-changes in the nominal capital stock measured as the net stock of private nonresidential assets. Some capital gains are never realized. For example, capital gains taxes are not paid by tax-exempt institutions such as pension funds. When assets with unrealized capital gains are bequeathed to heirs, the basis for the capital gains is reset to current market value and no capital gains tax is due on the increased asset value earned during the lifetime of the deceased. (Note: Those assets are still subject to estate taxes for higher-valued estates.)

${ }^{10}$ This calibration is consistent with Auerbach's (1988) regression results showing that a 1 percent increase in the capital gains tax rate is associated with a 0.56 percent decline in realized capital gains. A simulation experiment using the time-series property of Auerbach's data on capital gains realizations generates a similar result with an elasticity measure equal to -1.1 .

${ }^{11}$ The derivation of this result is in an appendix available upon request
} 
ple, $1+\phi_{\pi}>1$. When $\tau^{B}>0$, the value of $\phi_{\pi}$ necessary for the model to have a unique equilibrium rises as $\tau^{B}$ gets bigger. Edge and Rudd (2007) also show that the determinacy threshold value of $\phi_{\pi}$ rises as the value of $\phi_{y}$ increases. For our baseline model with $\phi_{y}=0$, the minimum value of $\phi_{\pi}$ needed for determinacy is approximately equal to 0.337 . When $\tau^{B}$ increases to 30 percent, the determinacy value of $\phi_{\pi}$ rises to approximately 0.414 .

One difference between regimes is the calibration of the driving process for the inflation target. We set $\rho_{\pi}$ equal to 0.97 in the early period and 0.84 in the late period based on estimates of the largest root in an augmented Dickey-Fuller equation used to test for unit roots. (See Gavin, Kydland, and Pakko, 2007.) Empirical evidence from the pre-1979 period finds that the inflation rate follows a stochastic trend and that the inflation premium in long-term interest rates displays a unit root. ${ }^{12}$ The problem for our model is that when the inflation target is a random walk, the tax effects from an energy shock are incredibly large in the early regime. Those shocks raise long-run inflation expectations and the expected tax on bond interest income and capital gains. Stock (1991) derives confidence intervals for the largest roots in the macro data set used by Nelson and Plosser (1982). For CPI inflation, the 80 percent confidence interval ranges from 0.922 to 1.031 . Our early regime value for $\rho_{\pi}$ lies in the middle of that range.

Our calibration of the size of the inflation rate target's response to an energy supply shock, $\xi$, depends on the policy regime. For both regimes, establishing a direct calibration target is difficult because the Fed did not have an explicit numerical objective for inflation until 2012. Kozicki and Tinsley (2005) estimate a time-series model with two unobserved variables-a perceived and an actual inflation target. In their framework, the actual inflation target accommodates, on average, 73 percent of each cost-push shock. ${ }^{13}$ While that paper's results are generally supportive of our early-regime calibration for $\xi$, their results are not directly transferrable to our specification.

Bernanke (2003) argues that the Fed accommodated higher oil prices during the 1970s but did not do so during the 1990s. To support his claim, Bernanke notes that during the 1970s "oil price shocks were in fact associated with substantial ... increases in core inflation." Evidence suggests that most major shocks that affected inflation in the 1970s were associated with the energy market. As noted above, empirical evidence supports the notion that long-run inflation expectations appeared to follow a random walk in this period. Our calibrated value of $\xi=0.072$ for the early period is consistent with the belief that the Fed did in fact accommodate cost-push shocks during that period. This paper focuses on cost-push shocks from changes in the energy supply because we are examining how such an accommodative policy impacts the observed relationship between energy and economic activity.

By the 1990s, Bernanke (2003) states that "oil price changes seemed to have no noticeable effect on core inflation." That analysis suggests that we should set $\xi$ to 0 in the late regime. Our results, however, do not depend on setting that parameter to zero because the lower value of $\rho_{\pi}$ calibrated for the late period will eliminate any persistent effect induced by having $\xi>0$. We report the sensitivity of our results to policy parameter values in the computational experiments in the next two sections.

\footnotetext{
${ }^{12}$ Ireland (2007) estimates a DSGE model of the U.S. economy. He finds that in the pre-1980 period the inflation target can be modeled as a random walk with exogenous shocks or as a stochastic trend that reacts to other economic shocks. Ellingsen and Soderstrom (2004) and Dewachter and Lyrio (2006) find that the inflation premium in long-term interest rates also has a unit root.

${ }^{13} \mathrm{An}$ energy shock is one type of cost-push shock.
} 


\subsection{The Data: Energy Shocks and Capital Gains}

What percentage of non-energy output fluctuations can be attributed to energy shocks in U.S. data? To answer that question, we estimate a bivariate VAR with energy and output. ${ }^{14}$ Energy is measured as the log of per capita energy from the personal consumption expenditures (PCE) component of GDP, while output is calculated as the log of per capita value of real PCE minus the energy component of PCE plus real investment. Figure 1 shows the energy shock (i.e., the energy residual identified in a Cholesky decomposition) for the periods 1973:Q1-1979:Q3 and 1983:Q12007:Q4. One key result from our estimated VAR model is that the standard deviation of the energy supply shock in the early period is twice the size of that in the late period. Figure 2 presents the dynamic responses of energy and output to a one-standard-deviation shock to the energy supply in that VAR. The left column displays the impulse responses for the early period, while the right column presents the responses for the late period. In both samples, the energy shocks are persistent and the effects on output are positive and significant. Note that the energy shock's contribution to the variance of output is much smaller in the late period than in the early period. Specifically, the first row of Table 2 shows that energy shocks account for 47.6 percent and 66.4 percent of output's variability at the 4- and 8-quarter forecast horizons, respectively, in the early period, but account for only 13.4 percent and 19.7 percent, respectively, in the late period.

The taxation of capital gains is quite complicated in the U.S. tax code. One prominent feature is that nominal capital gains are taxed, but only when they are realized. In this paper, all capital gains are generated from inflation in the price of capital goods. Income from capital that is paid to the households as dividends is taxed as capital income. In the U.S., most capital gains are earned by households in the higher income tax brackets. The statutory rate on long-term capital gains has always been lower than marginal income tax rates, so investors have had an incentive to retain capital income, reinvest it, and report the earnings as capital gains. Therefore, the data on reported capital gains includes nominal income from both capital income that is held as retained earnings and inflation in the price of the capital stock.

Figure 3 illustrates that relative size of two measures of capital gains from 1949 through 2010. The solid blue line displays the change in the price of investment goods multiplied by the capital stock as a fraction of nominal GDP. That data series is the counterpart to the model definition of accrued capital gains, $\left(P_{n, t}-P_{n, t-1}\right) k_{t}$, divided by nominal GDP. Furthermore, that ratio is understated, on average, because it should also include the price changes in manufacturing and trade inventories, which account for about 10 percent of the level of private nonresidential fixed capital stock. The big spikes in the series are due to jumps in inflation. This figure illustrates that capital gains from inflation were high, volatile, and represented a sizeable share of GDP before 1983, but not afterward.

The dashed red line in Figure 3 shows the value of realized capital gains as a share of GDP. This data represents capital gains reported for tax purposes and includes the components from both inflation and real capital income that was not paid out as dividends. The first spike in realized capital gains occurs in 1986 as a result of a legislated increase in the statutory capital gains tax that commenced in 1987. After the legislation passed in May 1986, investors sharply increased their realization of capital gains in order to avoid paying a substantially higher tax rate after that period. The legislation raised the maximum statutory rate on long-term capital gains from 20 percent in 1986 to 28 percent in 1987. In the NBER TAXSIM time series, the average marginal tax rises from

\footnotetext{
${ }^{14}$ The VAR also includes two lags and a time trend.
} 
17.97 percent in 1986 to 24.52 percent in 1987 . The second spike happens in the late $1990 \mathrm{~s}$ and is caused by the enormous increase in equity prices from the dot-com boom. The third spike occurs in the mid-2000s and is due to the asset price inflation associated with the Fed's very low interest rate policy prior to the 2008 financial crisis. In the last two cases, a large share of the realized capital gains are short-term in nature that by law are taxed at the higher personal income tax rate.

\section{Computational Experiments}

This section examines the effects of energy supply shocks on the economy under alternative assumptions about monetary policy, taxes, and the structure of the energy sector. The key issue that we investigate is why energy appears to impact the economy so much more before 1980 and so much less afterward. In our analysis, the two periods are treated as separate monetary policy regimes and each period has its own level of efficiency in energy use. We proceed to explain how monetary policy interacts with the tax code and show how capital gains and bond income taxes influence the effects of energy shocks on the economy.

\subsection{Model Results}

In the early regime, the Fed accommodates a temporary increase in energy prices caused by a negative energy supply shock by raising its inflation rate target. It does not, however, adjust its inflation target in response to an energy shock in the late regime. A persistent 1-percent negative energy supply shock takes about 10 years to decay back to its steady state. Figure 4 displays the impulse responses of key economic variables for the following three specifications: the early regime is indicated by a solid blue line; the early regime with late-regime energy shares is indicated by a dashed-dot green line; and the late regime is indicated by a dashed red line. The area between the solid blue line and the dashed-dot green line represents the effect due to the smaller energy shares in consumption and output. The area between the dashed-dot green line and the dashed red line shows the effect from different monetary policy parameters. In Figure 4, the vertical axis of each chart reports the percent deviation from the steady state. The horizontal axis displays the number of quarters, from 0 to 100. In the top two panels, inflation and the interest rate are shown at quarterly rates. In the bottom right panel, the figure shows the deviation of the ratio of realized capital gains to output from its steady-state ratio, which is 2.3 percent.

Higher energy prices following a negative energy supply shock push up production costs, which in turn encourages firms to raise prices. In the early regime, the inflation target process is very persistent, $\rho_{\pi}=0.97$, and the Fed raises its inflation rate target, $\xi>0$, to accommodate higher energy prices. Inflation rises more in that regime because the public knows that the Fed is soft on inflation. The inflation increase in the late regime, however, is much smaller because the inflation target is less persistent, $\rho_{\pi}=0.84$, and the Fed does not accommodate higher energy prices by changing the inflation target, $\xi=0$. In other words, the Fed is more hawkish in fighting inflation. As Equation (18) demonstrates, the presence of the bond interest income tax introduces another term into the condition for determinacy in the nominal interest rate rule. That tax effectively lowers the central bank's response to inflation for any given value of $\phi_{\pi}$. Intuitively, the inflation rate, the nominal interest rate, and the pre-tax real interest rate have to rise enough to pay the fluctuating tax on bond interest income. The after-tax real interest rate, on the other hand, remains relatively 
constant, as in a standard RBC model. That tax mechanism is present in both regimes, but a more aggressive monetary policy against inflation in the late regime helps minimize the effects of energy shocks on the economy.

The nominal interest rate responses look similar to those for inflation. In the policy rule, a value of $\phi_{\pi}>0.339$ means that the nominal interest rate jumps more than inflation. Inflation and the nominal interest rate move less in the early regime with the late-regime energy shares because the value of $\xi$ is lower, 0.046, reflecting the smaller share of energy in the consumer basket. As demonstrated below, the important effect of the late-regime energy shares on inflation and interest rates comes from the fact that the coefficient on the energy shock in the inflation target equation, $\xi$, is equal to the smaller share of energy in consumption. The lower persistence in the inflation target and no accommodative policy response to an energy shock in the late regime keeps inflation and interest rates even closer to the steady state.

The 1-percent energy shock causes an immediate decline in output of about 0.2 percent in the early regime, which is slightly more than double the effect in the late regime. The large jump in inflation expectations in the early regime raises the expected capital gains tax. That higher tax acts as a negative wealth shock and amplifies the drop in output after a negative energy shock. Initially, the higher energy share and the more accommodative monetary policy are responsible for about an equal amount of the additional output decline. In subsequent periods, however, the impact from the higher energy share dissipates more quickly, so that by year 10 most of the additional fall in output is due to the loose monetary policy of the early regime. The response of consumption to an energy shock is influenced by households' ability to smooth consumption by selecting the timing of when to realize accrued capital gains. Immediately following a negative energy shock, households delay the realization of capital gains and reduce investment to mitigate a drop in consumption. That decline in consumption continues for the next 20 or so quarters in the early regime, but quickly reverses course in the late regime.

The energy shock reduces the combined energy/capital input and, as a result, pushes down the marginal product of labor. A lower marginal product of labor reduces both labor demand and the real wage, which encourages households to substitute away from work and toward leisure. When the effects of the energy shock are amplified and propagated by monetary policy, households expect the capital stock to decline for a longer period of time and anticipate that the real wage will remain persistently low in the near term. As time progresses, labor hours recover faster than the real wage or the capital stock. The reason why labor returns to its steady state more quickly is that the wealth effect from a lower capital stock mitigates the substitution effect caused by a lower real wage.

The capital stock falls in response to a lower supply of energy. The direct effect of less energy is a reduction in the marginal product of capital. That effect is enhanced by the temporary increase in the expected tax on capital gains. When the inflation target is very persistent (i.e., $\rho_{\pi}$ is large), the expected tax on capital gains rises substantially, which further pushes down the capital stock. The higher inflation also pushes up accrued capital gains. Households, however, initially decide to reduce their realized capital gains in order to decrease their short-term tax liability. Smaller tax payments provide households additional resources to offset some of the decline in consumption caused by a drop in their income. After 10 quarters, households' incomes have started to recover, which enables them to increase realized capital gains and pay the additional associated taxes. 


\subsection{Inspecting the Mechanism: Monetary Policy and the Tax Code}

Both monetary and fiscal policy influence the effects of energy shocks on the economy. Although monetary policy determines how inflation responds to energy shocks, the tax code, which is imperfectly indexed to inflation, controls how the real economy reacts to changes in inflation expectations. Our model ignores the lack of inflation indexing in labor and capital income taxes present in the economy prior to the Tax Reform Act of 1981. Findings by Altig and Carlstrom (1991) suggest that the direction and magnitude of our results would be stronger if we incorporated the pre-1981 tax code in the model. Our focus, however, is on modeling the economic effects of an energy shock in a specification that includes the tax structure currently in place. In other words, we specify a tax code in which only bond interest income and capital gains taxes are not indexed to inflation. This analysis would be particularly useful to policymakers if the Fed were deciding whether or not to implement a monetary regime in which they adjust their inflation target in response to energy shocks. ${ }^{15}$

To examine the sensitivity of our results, we analyze the effects of key monetary and fiscal policy parameters on consumption's response to a 1-percent negative energy supply shock. Our focus is to determine the longer-term effects of a negative energy shock on consumption. We examine the present value of consumption deviations rather than that of output because consumption is more intuitively associated with welfare effects. Furthermore, long-run consumption and output behavior are very similar. Figure 5 displays the sensitivity of consumption's response to a 1-percent energy shock as a function of four key policy parameters, the tax rates on capital gains and bond interest income, as well as the monetary policy parameters in the inflation target equation. In each panel, the values on the vertical axis represent the present value of consumption lost following a 1-percent negative energy shock. ${ }^{16}$ The losses are measured as percent deviations from the steady state. In the baseline early regime model, a 1-percent negative energy shock generates a loss in the present value of consumption of 4.65 percent. That loss is denoted on each chart by a circle marker. When the monetary policy from the late regime $\left(\rho_{\pi}=0.84\right.$ and $\left.\xi=0\right)$ is imposed on the early regime, the present value of the consumption loss is only 2.84 percent. ${ }^{17}$

The top row of Figure 5 shows how the consumption loss changes with the statutory tax rates on capital gains, $\tau^{G}$, and bond interest income tax, $\tau^{B}$. Higher values of $\tau^{G}$ enhance the negative wealth effect from increased inflation, which causes consumption and capital investment to fall. With less capital investment, future consumption also falls, which contributes to the slight nonlinear response of the consumption loss to changes in $\tau^{G}$. Increased values of $\tau^{B}$ have a much greater nonlinear effect on the consumption loss because the higher tax rate interacts with the inflation

\footnotetext{
${ }^{15}$ There is a substantial amount of literature on how monetary policy has responded or should respond to energy or oil price shocks. That literature, however, does not take into account the tax code. See, for example, Leduc and Sill (2004), Bodenstein, Erceg, and Guerrieri (2011), and Kormilitsina (2011).

${ }^{16}$ These are approximations to the present value using computed values for the first 100 quarters,$$
P V=\sum_{i=0}^{i=99} \beta^{i} x_{t+i}
$$

where $\beta=0.99$ and the elements of $x_{t}$ are deviations of model variables from their steady states.

${ }^{17}$ This specification assumes that energy shares of consumption and output are equal to their early regime values and that all of the tax rates are at their baseline values. If, however, the specification does not include any taxes, then the consumption loss would fall to 2 percent.
} 
coefficient, $\phi_{\pi}$, in the Taylor rule to move the model closer to its determinacy boundary. Raising $\tau^{B}$ essentially has the same effect as lowering $\phi_{\pi}$ in the sense that both changes exacerbate the economy's response to an energy shock. When $\tau^{B}$ rises to around 31 percent, our calibrated model of the early regime no longer generates a unique equilibrium.

The bottom row of Figure 5 illustrates the impact of monetary policy on the size of the consumption loss. The inflation rate target persistence parameter, $\rho_{\pi}$, has an extremely nonlinear effect on the consumption loss following a 1-percent negative energy shock. When $\rho_{\pi}=0.84$, as it is in the late regime, the consumption loss is only 2.88 percent, which is only 0.04 percent higher than when $\rho_{\pi}=0$. The consumption loss starts to grow more sharply as $\rho_{\pi}>0.9$. As $\rho_{\pi}$ gets close to unity, an energy shock generates a considerable amount of consumption loss because the shock begins to behave as if it is permanently raising the inflation rate target. Finally, the extent to which the Fed decides to accommodate energy shocks, $\xi$, has a linear effect on the consumption loss. When the Fed does not accommodate energy shocks $(\xi=0)$, that loss is only 2.84 percent which is equivalent to its loss when $\rho_{\pi}=0$. Thus, the consumption loss from a negative energy shock can be reduced substantially by either lowering $\rho_{\pi}$ below 0.9 or by not accommodating energy shocks $(\xi=0)$.

Our sensitivity tests in Figure 5 reveal that in the early regime the taxation of nominal capital gains and bond interest income combined with a persistent inflation target $\left(\rho_{\pi}=0.97\right)$ and a monetary accommodation of energy shocks $(\xi=0.072)$ created a perfect storm that exaggerated the effects of energy shocks. The results indicate that a drastic reduction in any one of those fiscal or monetary policy parameters would generate a much smaller loss in consumption. Thus, the reduced economic volatility after an energy shock observed in the late regime can be attributed, in part, to the lower values of $\rho_{\pi}$ and $\xi$.

\section{Conclusion}

This paper investigates how the oil price shocks of the 1970s could have led to both a large decline in output and hours worked and a sharp rise in the inflation rate. Prior to 1980, the Fed responded to oil price shocks by allowing the inflation rate to rise. Although the Fed raised interest rates following the 1970s oil shocks, that particular increase was insufficient to prevent inflation and long-run inflation expectations from rising. As a result, higher inflation increased the effective taxes on both bond interest income and capital gains. Capital gains taxes are paid on realized capital gains, so the accrual equivalent tax rate is much lower than the statutory tax rate. Households select when to pay the capital gains taxes and can avoid those taxes entirely on about 60 percent of the gains. For example, capital gains taxation can be avoided taxation by placing funds in tax-exempt retirement accounts or by bequeathing the capital to heirs. Nevertheless, that mechanism is still powerful enough to generate sizable real effects from oil price shocks. Once Fed Chairman Paul Volcker adopted a disinflationary policy and stopped accommodating energy price shocks, the impact of oil price shocks on the economy was greatly reduced.

Our model generates solutions for some apparent problems from the 1970s macroeconomic experience. First, it explains why the real economy reacted so sharply to the first oil shocks and how both a stagnant economy and high inflation could exist simultaneously. Second, it rationalizes

why the real effects from an oil price shock dissipated after 1980 and accounts for the apparent asymmetry in the response of the economy to positive and negative shocks. The large negative 
shocks that occurred in the 1970s were accompanied by an easier monetary policy that amplified the real effects. The positive shocks in the later period occurred after the Fed had earned credibility for its low-inflation policy.

This paper contributes to our understanding of the past, but also carries an important warning for policymakers today. Since bond interest income and capital gains taxes are still not indexed to inflation, reversion to a monetary policy regime that accommodates energy price shocks risks returning us to the high inflation and slow growth economy of the 1970s. Some economists argue that the Fed should raise the inflation target but for a variety of different reasons, including the zero lower bound on interest rates, the large stock of outstanding government debt, the loss of home equity during the financial crisis, the high unemployment rate, and the rising cost of crude oil. Each of those recommendations must be evaluated separately on its merits in a model that includes the relevant features. One critical feature that should be included in any business cycle model is the tax code and how it interacts with inflation under the proposed monetary policy regime. 


\section{References}

[1] Aguiar-Conraria, Luis, and Yi Wen. "Understanding the Large Negative Impact of Oil Shocks.” Journal of Money, Credit and Banking, June 2007, 39(4), 925-944.

[2] Alpanda, Sami, and Adrian Peralta-Alva. "Oil Crisis, Energy-Saving Technological Change and the Stock Market Crash of 1973-1974." Review of Economic Dynamics, October 2010, 13(4), 824-842.

[3] Altig, David, and Charles Carlstrom. "Inflation, Personal Taxes, and Real Output: A Dynamic Analysis.” Journal of Money, Credit and Banking, August 1991, 23(3), 547-571.

[4] Anagnostopoulos, Alexis, Eva Cárceles-Proveda, and Danmo Lin. "Dividend and Capital Gains Taxation under Incomplete Markets." Journal of Monetary Economics, November 2012, 59(7), 599-611.

[5] Auerbach, Alan J. "Capital Gains Taxation in the United States: Realizations, Revenue, and Rhetoric.” Brookings Papers on Economic Activity, 1988, 2, 595-631.

[6] Baily, Martin N. "Productivity and the Service." Brookings Papers on Economic Activity, 1981, 1, 1-50.

[7] Bernanke, Ben S. "Constrained Discretion' and Monetary Policy." Remarks Before the Money Marketeers of New York University. New York, New York, February 3, 2003.

[8] Bodenstein, Martin, Christopher J. Erceg, and Luca Guerrieri. “Oil Shocks and External Adjustment.” Journal of International Economics, March 2011, 83(2), 168-184.

[9] Dewachter, Hans, and Marco Lyrio. "Macro Factors and the Term-Structure of Interest Rates." Journal of Money, Credit and Banking, February 2006, 38(1), 119-140.

[10] Dhawan, Rajeev, Karsten Jeske, and Pedro Silos. "Productivity, Energy Prices, and the Great Moderation: A New Link.” Review of Economic Dynamics, July 2010, 13(3), 715-724.

[11] Díaz, Antonia, and Luis A. Puch. "A Theory of Vintage Capital Investment and Energy Use," Manuscript, University Carlos III de Madrid, December 2013.

[12] Edge, Rochelle M., and Jeremy B. Rudd. "Taxation and the Taylor Principle." Journal of Monetary Economics, November 2007, 54(8), 2554-2567.

[13] Ellingsen, Tore, and Ulf Soderstrom. "Why are Long Rates Sensitive to Monetary Policy?" IGIER Working Paper 256, March 2004.

[14] Feenberg, Daniel R., and James M. Poterba. "The Alternative Minimum Tax and Effective Marginal Tax Rates.” NBER Working Paper 10072, November 2003.

[15] Finn, Mary G. "Perfect Competition and the Effects of Energy Price Increases on Economic Activity." Journal of Money, Credit and Banking, August 2000, 32(3), 400-416. 
[16] Gavin, William T., Finn E. Kydland, and Michael R. Pakko. "Monetary Policy, Taxes, and the Business Cycle.” Journal of Monetary Economics, September 2007, 54(6), 1587-1611.

[17] Ghez, Gilbert R., and Gary S. Becker. "The Allocation of Time and Goods over the Life Cycle." Columbia University Press, New York, 1975.

[18] Hamilton, James D. "Oil and the Macroeconomy Since World War II." Journal of Political Economy, April 1983, 91(2), 228-248.

[19] Hamilton, James D. "Causes and Consequences of the Oil Shock of 2007-2008." Working Paper University of California, San Diego, April 27, 2009.

[20] Hooker, Mark A. "What Happened to the Oil-Price Macroeconomy Relationship?" Journal of Monetary Economics, October 1996, 38(2), 195-213.

[21] Ireland, Peter N. "Changes in the Federal Reserve's Inflation Target: Causes and Consequences.” Journal of Money, Credit and Banking, December 2007, 39(8), 1851-1882.

[22] Kilian, Lutz. "Not All Oil Price Shocks Are Alike: Disentangling Demand and Supply Shocks in the Crude Oil Market." American Economic Review, June 2009, 99(3), 1053-1069.

[23] Kim, In-Moo, and Prakash Loungani. "The Role of Energy in Real Business Cycle Models." Journal of Monetary Economics, April 1992, 29(2), 173-189.

[24] Kormilitsina, Anna. "Oil Price Shocks and the Optimality of Monetary Policy." Review of Economic Dynamics, January 2011, 14(1), 199-223.

[25] Kozicki, Sharon, and P.A. Tinsley. "Permanent and Transitory Policy Shocks in an Empirical Macro Model with Asymmetric Information." Journal of Economic Dynamics and Control, November 2005, 29(11), 1985-2015.

[26] Leduc, Sylvan, and Keith Sill. "A Quantitative Analysis of Oil Price Shocks, Systemic Monetary Policy, and Economic Downturns.” Journal of Monetary Economics, May 2004, 51(4), 781-808.

[27] Lucas, Robert. E., Jr. “Inflation and Welfare.” Econometrica, March 2000, 68(2), 247-274.

[28] Mulligan, Casey B., and Xavier X. Sala-i-Martin. "The Optimum Quantity of Money: Theory and Evidence.” Journal of Money, Credit and Banking, November 1997, 29(4), 687-715.

[29] Nelson, Charles R., and Charles I. Plosser. "Trends and Random Walks in Macroeconomic Time Series with a Unit Root.” Journal of Monetary Economics, 1982, 10(2), 139-162.

[30] Rotemberg, Julio, and Michael Woodford. "Imperfect Competition and the Effects of Energy Price Increases on Economic Activity." Journal of Money, Credit and Banking, November 1996, 28(4), 549-577.

[31] Schorfheide, Frank. "Learning and Monetary Policy Shifts." Review of Economic Dynamics, April 2005, 8(2), 392-419. 
[32] Stock, James H. "Confidence Intervals for the Largest Autoregressive Root in U.S. Macroeconomic Time Series.” Journal of Monetary Economics, December 1991, 28(3), 435-459.

[33] Taylor, John B. "Discretion versus Policy Rules in Practice." Carnegie-Rochester Conference Series on Public Policy, 1993, 39, 195-214.

[34] Wei, Chao. "Energy, the Stock Market, and the Putty-Clay Investment Model." American Economic Review, March 2003, 93(1), 311-324. 
Figure 1. Energy Shock*

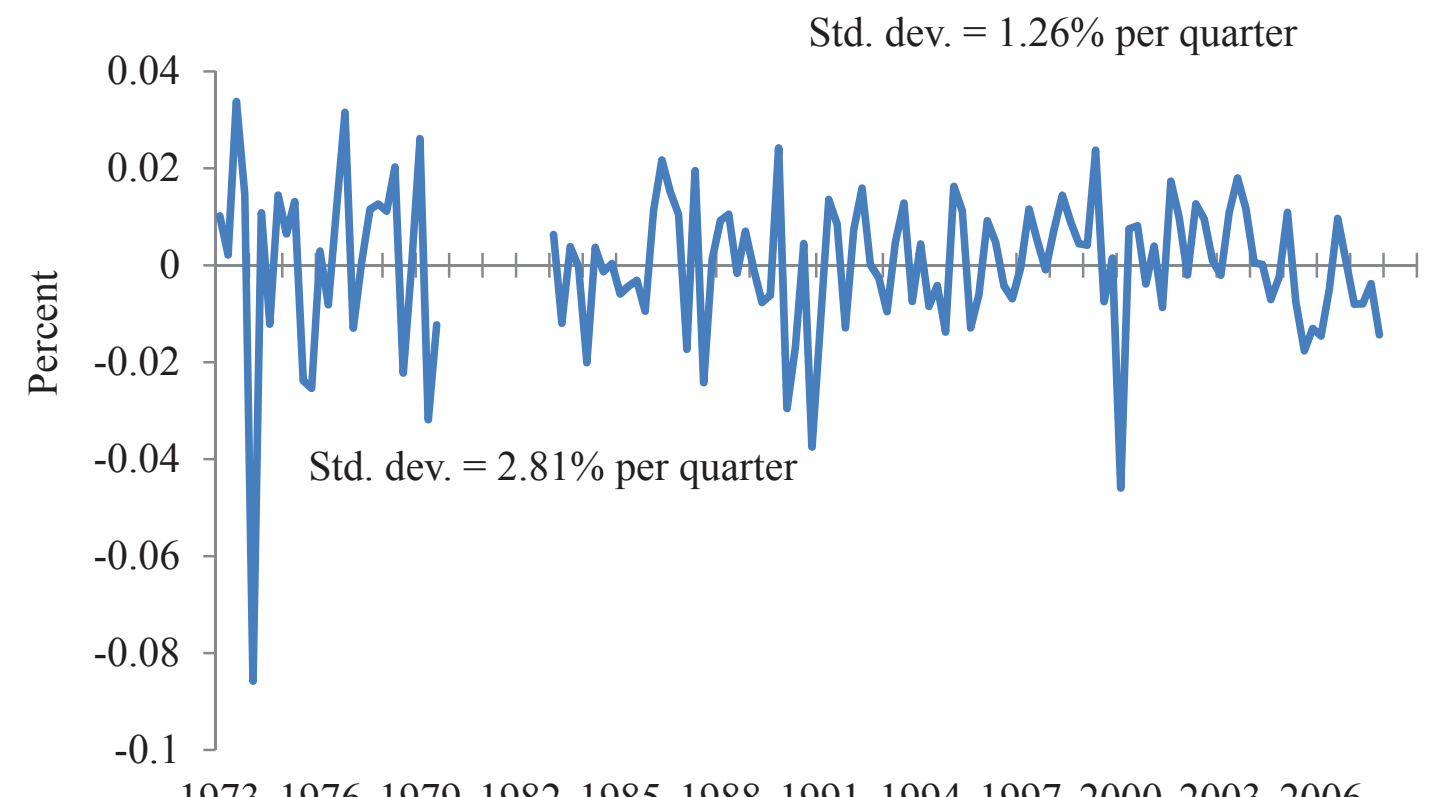

197319761979198219851988199119941997200020032006

* Energy is measured as the energy component of PCE. The energy shock is the residual in a bivariate VAR with private output excluding energy. Energy shocks are identified with a Cholesky decomposition in which energy is the first variable. The periods 1979:Q4 to 1982:Q4 and post-2007 are excluded because the monetary policy rules were very different and inconsistent with our model assumptions during these periods. The VARs include two lags and a time trend as well as the log of per capita real energy and the log of per capita real output. 
Figure 2. VAR Responses to a Positive 1 Std. Dev. Energy Supply Shock*
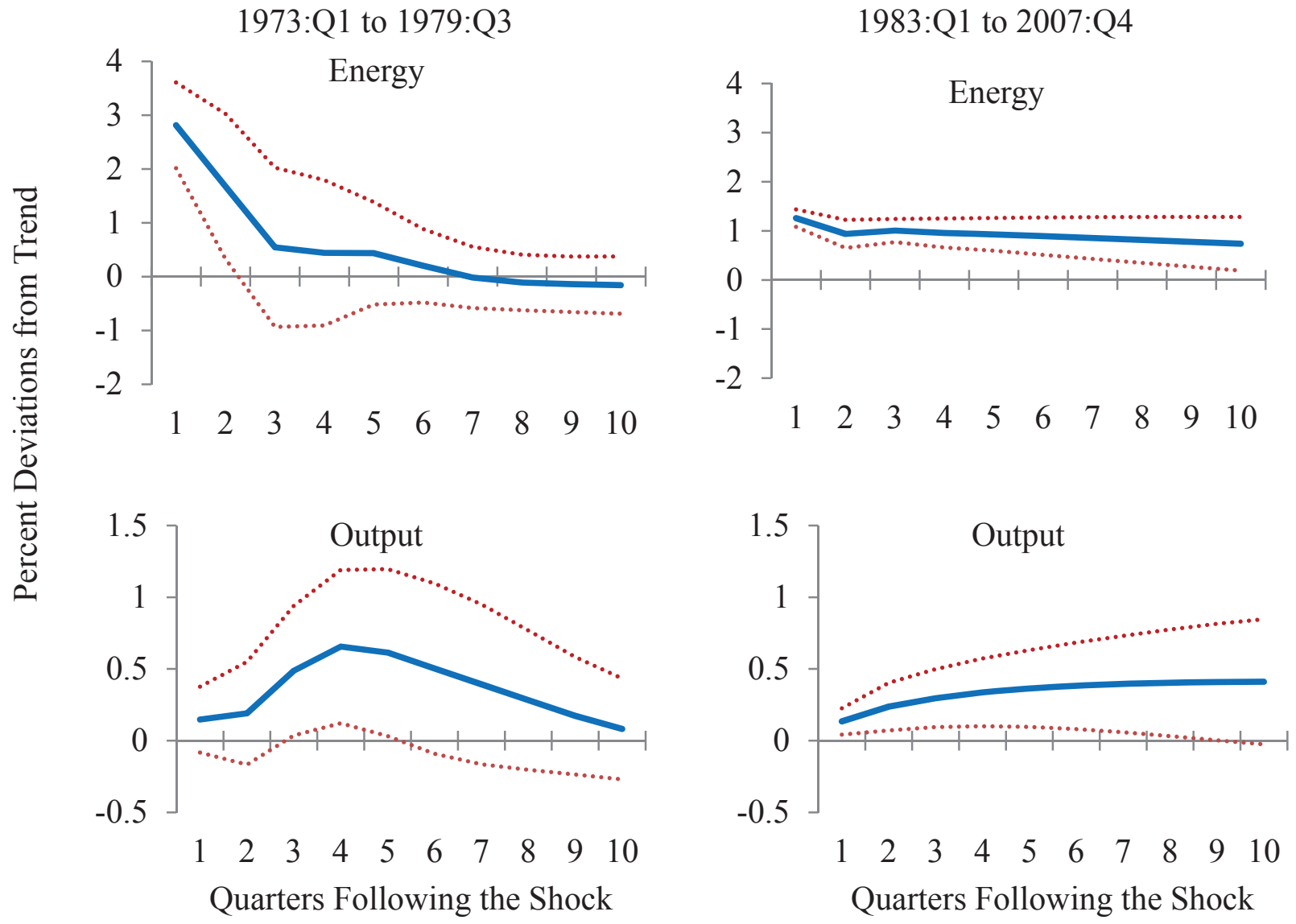

* The impulse responses are identified in a Cholesky decomposition with energy as the lead variable. The dotted red lines are equal to the impulse response plus or minus two standard deviations. 
Figure 3. Inflation and Realized Capital Gains*

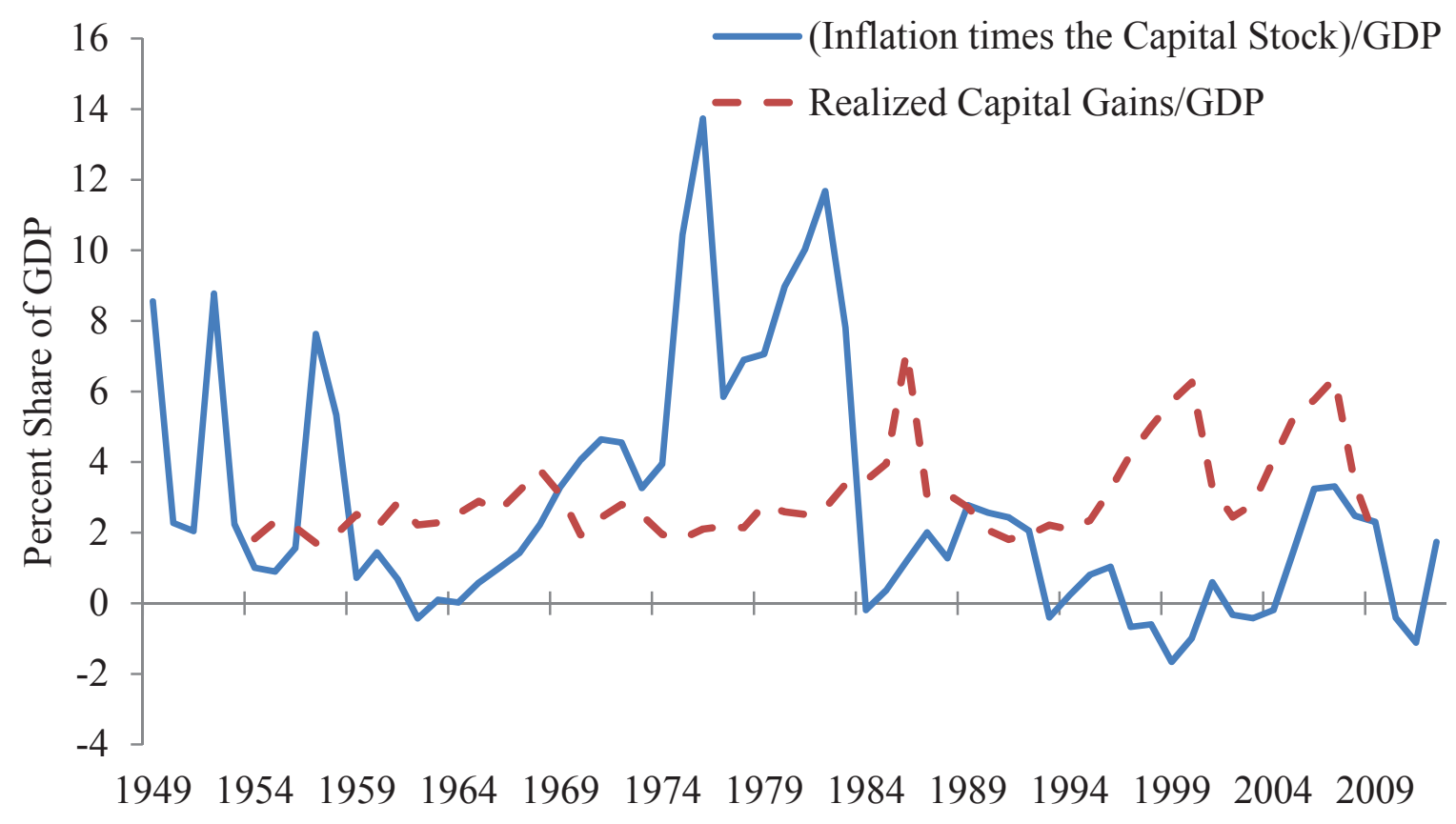

* Inflation here is measured as the deflator for private nonresidential fixed investment. The capital stock is the net stock of private fixed nonresidential assets. GDP here is measured in current U.S. dollars. Realized capital gains are total realized capital gains in current U.S. dollars. 
Figure 4. Model Responses to a 1 Percent Adverse Energy Shock

Early regime — Early regime-late shares - : - Late regime - - -
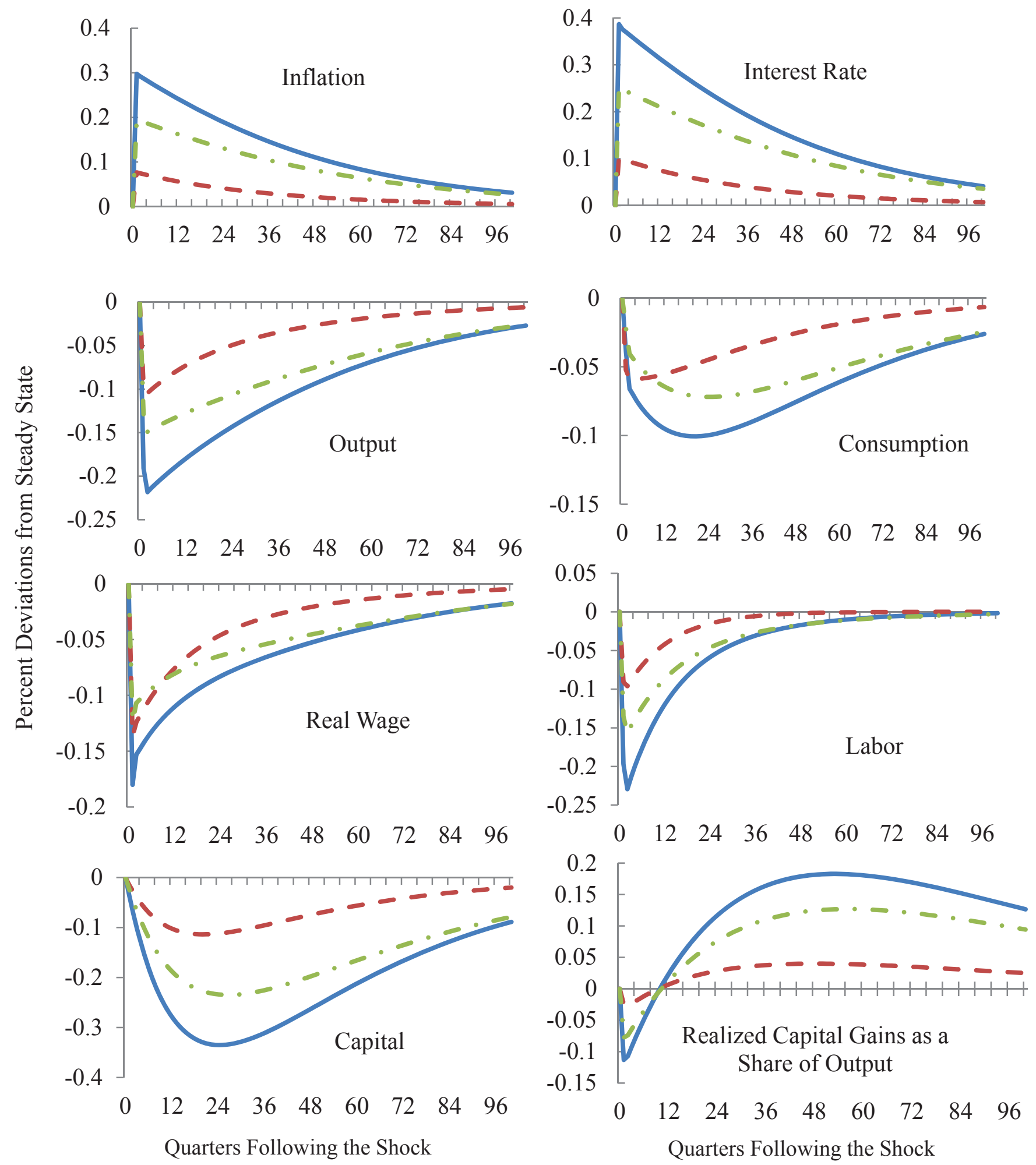
Figure 5. Sensitivity of the Consumption Loss to Policy Parameters*
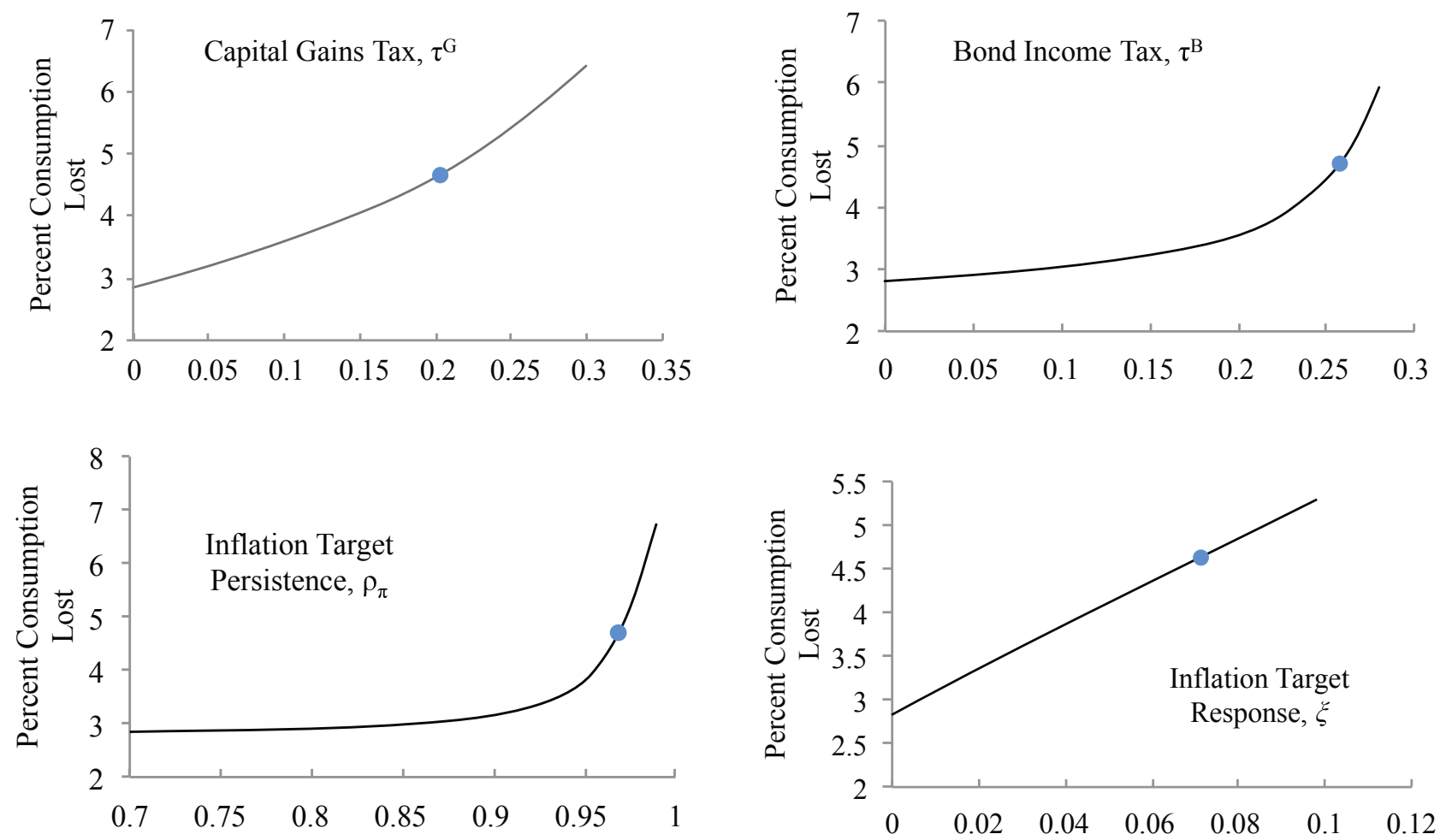

* The values on the vertical axis represent the present value of consumption lost following a 1-percent negative energy supply shock. The computations are from the Early Regime baseline calibration, which is indicated by the circles in each panel. 
Table 1. Parameter Assignments

\begin{tabular}{lcc}
\hline Parameter & Symbol & Value* \\
& & \\
\hline Depreciation rate & $\delta$ & 0.025 \\
Discount factor & $\beta$ & 0.99 \\
Relative risk aversion & $\sigma$ & 2 \\
Capital share in production & $\alpha$ & 0.33 \\
Shopping-time parameter & $\eta$ & 1 \\
Steady-state share of labor time & $N$ & 0.3 \\
Steady-state share of shopping time & $S$ & 0.003 \\
Labor tax rate & $\tau^{n}$ & 0.24 \\
Capital tax rate & $\tau^{k}$ & 0.34 \\
Bond tax rate & $\tau^{B}$ & 0.26 \\
Capital gains tax rate & $\tau^{G}$ & 0.20 \\
Steady-state ratio of realized to accumulated & $G / U$ & 0.0094 \\
capital gains & $\zeta$ & -1.1 \\
Elasticity of marginal adjustment costs w.r.t. G/U & $\gamma_{x}$ & 1.004 \\
Steady-state output growth & $\gamma_{p}$ & 1.01 \\
Steady-state inflation & $v^{f}$ & -0.9 \\
CES capital/energy substitution parameter & $v^{h}$ & -0.9 \\
CES consumption/energy substitution parameter & $\psi$ & $0.053 / 0.037$ \\
Energy share in production & $e_{c} / c$ & $0.072 / 0.046$ \\
Energy share used in consumption & $\phi_{\pi}$ & 0.5 \\
Fed's reaction to inflation & $\phi_{y}$ & 0.125 \\
Fed's reaction to output & $\xi$ & $0.072 / 0$ \\
Inflation target response to energy shock & $\sigma_{e}$ & $0.0281 / 0.0126$ \\
S.D. of the energy shock & $\rho_{e}$ & 0.92 \\
Persistence in energy & $\rho_{\pi}$ & $0.97 / 0.84$ \\
Persistence in the inflation target & $\sigma_{z}$ & $0.0059 / 0.0047$ \\
S.D. of the technology shock & $\rho_{z}$ & 0.95 \\
Persistence in technology & & \\
\hline
\end{tabular}

*If two values are shown, they represent the early/late regimes. 
Table 2. Contribution of Energy Shocks to the Forecast Error Variance of Output

\begin{tabular}{|c|c|c|c|c|}
\hline & \multicolumn{2}{|c|}{ 1973:Q1 to 1979:Q3 } & \multicolumn{2}{|c|}{ 1983:Q1 to 2007:Q4 } \\
\hline U.S. Data ${ }^{1}$ & 4-quarter & 8 -quarter & 4-quarter & 8 -quarter \\
\hline Energy component in PCE & $47.6 \%$ & $66.4 \%$ & $13.4 \%$ & $19.7 \%$ \\
\hline Model results ${ }^{2}$ & \multicolumn{2}{|c|}{ Early regime } & \multicolumn{2}{|c|}{ Late regime } \\
\hline Baseline & $29.82 \%$ & $30.15 \%$ & $2.9 \%$ & $2.7 \%$ \\
\hline
\end{tabular}

${ }^{1}$ These values are calculated using a bivariate VAR with U.S. data.

${ }^{2}$ These values are calculated using the two shocks, technology and energy, in the model. 